\title{
EARLY CHRISTIAN ESCHATOLOGICAL EXPERIENCE IN THE WARNINGS AND EXHORTATIONS OF THE EPISTLE TO THE HEBREWS
}

\author{
Scott D. Mackie
}

\begin{abstract}
Summary
This essay examines the characteristics and rhetorical function of the many eschatological experiences found in Hebrews' warnings against apostasy and exhortations to persevere. In these two contexts we see the vital connection of the author's hortatory effort to the community's eschatological experiences. Warnings of the dire consequences of forsaking the community are often substantiated by appeals to the community's eschatological experiences, both past and present. Similarly, exhortations to persevere are frequently supported by reminders of past and present supernatural experiences. The primary experiential motif found in these exhortations pertains to the community's identity as the family of God. This essay concludes with the novel claim that the author's Christological doctrine, hortatory effort, and the community's eschatological experiences are mutually interdependent.
\end{abstract}

\section{Introduction}

Critical appreciation for early Christian eschatological experience has come a long way since Rudolf Bultmann dismissively reduced Hebrews 6:4-5 (which describes the addressed community as 'those who have been enlightened, tasted the heavenly gift, shared in the Holy Spirit, and tasted the goodness of the word of God and the powers of the age to come') to: 'Does all this solemn description really mean 
anything more than that they have been baptized?' ${ }^{1}$ Despite the many advances that have been made in recent years, there is still much to be done, and the Epistle to the Hebrews, which was generally neglected for so long, is particularly well suited to repay attention to its eschatological experiential content.

In fact, Hebrews is one of the most eschatologically oriented books in the New Testament. Like most early Christians, the author of Hebrews was convinced the Christ event had inaugurated the eschaton, thus signalling the imminent end of both the earthly realm and the present age, and the present accessibility by faith of the heavenly realm and future age (1:2; 9:26; cf. 1 Pet. 1:19-21; Gal. 4:4-5; 1 Cor. 10:11). The presence of miraculous occurrences and profound spiritual experiences in early Christian communities were also seen as eschatological consequences of the Christ event. The author of Hebrews everywhere assumes the community he is addressing is familiar with these eschatological experiences (which might be defined as supernatural, transformative manifestations of the future, heavenly age, bestowed by Jesus, the resurrected and exalted Son of God, on his community, as proleptic foretastes of his divine glory and universal lordship). This essay focuses on the crucial role played by these experiences in the author's hortatory effort, particularly his warnings against apostasy and exhortations to persevere. Most remarkably, he even stakes the success of his 'word of exhortation' on them, as his calls to 'hold fast' and warnings against 'falling away' are almost entirely substantiated by appeals to the community's past and present eschatological experiences $(2: 1-4 ; 3: 6,14 ; 4: 1-3,14 ; 6: 4-6 ; 9: 28$; $10: 10-39 ; 12: 1-17)$. These experiences, which serve as divine 'testimonies' to the truth of the gospel (2:4), as well as the veracity of the warnings and exhortations, include 'signs, wonders, and miracles', heavenly rest, 'partaking' of the Spirit and Christ, 'tasting the powers of the age to come', enlightenment, and 'drawing near' to God and Jesus in the heavenly sanctuary. The most important eschatological experiences, however, pertain to the community's identity, as the author repeatedly appeals to and attempts to reinforce the community's sense of belonging in the family of God $(2: 12-13 ; 3: 6,14 ; 4: 14 ; 10: 23$; 12:5-17). This recurring familial orientation has not yet received an in-

1 R. Bultmann, Theology of the New Testament (2 vols.; New York: Scribner's, 1951, 1955): 2.166. 
depth critical analysis; and while some have briefly noted the rhetorical importance of other eschatological experiences in the warnings and exhortations, a sustained treatment is lacking. Finally, the author's seamless interweaving of Christological doctrine and exhortation has been frequently acknowledged; this essay will also attempt to demonstrate that the community's eschatological experiences should be considered just as integral to the rhetorical fabric of Hebrews.

\section{Warnings against Apostasy}

Hebrews contains what are perhaps the most severe warnings against apostasy in the entire New Testament. Positioned strategically throughout his exhortation are three major warnings of the consequences of abandoning the community, $2: 1-4 ; 5: 11-6: 12 ; 10: 26-$ 31 , all of which contain reminders of the recipients' supernatural experiences. ${ }^{2}$ The focus of most critical discussions of these passages, especially the latter two, 5:11-6:12 and 10:26-31, has been directed towards the nature and scope of the apostasy described by the author; specifically, whether it is theoretical, or if it reflects his (and possibly the community's) awareness of an instance, or instances, of irrevocable apostasy. ${ }^{3}$ The presence of three such threats, spread throughout the 'word of exhortation' (6:4-8; 10:26-29; 12:16-17), suggests they were not the result of a fit of passion. ${ }^{4}$ Conversely, the author's confident

2 See my discussion of the community's situation in Eschatology and Exhortation in the Epistle to the Hebrews (WUNT 2/223; Tübingen: Mohr Siebeck, 2007): 9-17. The author's rhetorical program is almost entirely directed towards a perceived threat to the existence of the community; as a result, a number of theories concerning the community's circumstances have been proposed, including impure consciences, persecution, a return to Judaism, waning commitment, and the loss of social status. Furthermore, a recurring emphasis on suffering suggests the community was encountering, or had encountered, circumstances that caused them to question their commitment.

3 Of course a great deal of energy has been expended in making the improbable argument that the 'apostates' of 6:4-6 and 10:26-31 were never genuinely converted, thus preserving the doctrines of 'the perseverance of the saints' and 'the eternal security of the believer'. See the recent critique of B. J. Oropeza, 'The Warning Passages in Hebrews: Revised Theologies and New Methods of Interpretation', Currents in Biblical Research 10.1 (2011): 81-100, esp. 82-86, 95-96.

4 See P. Ellingworth, The Epistle to the Hebrews (NIGTC; Grand Rapids: Eerdmans, 1993): 79: 'It is true that the writer never states that anyone in the community has actually committed apostasy; yet the language in places is so strong that the author must have considered it a real danger.' However, S. McKnight, 'The Warning Passages of Hebrews: A Formal Analysis and Theological Conclusions', Trinity Journal 13 
assurance in 6:9, that the 'beloved ones' will pursue and receive 'better things that pertain to salvation', would seem to suggest the warnings were somewhat rhetorical, and thus theoretical, at this point in the community's life. ${ }^{5}$ Whatever the case may be, as a result of the critical preoccupation with the issue of apostasy, the characteristics and rhetorical function of the eschatological experiences have not yet received the degree of attention they merit.

\subsection{Hebrews 2:1-4}

The exordium's declaration that the Christ event represents God's eschatological revelation (1:1-4), and the evocative description of Jesus' exaltation to universal lordship in 1:5-13, are both enlisted in the first warning passage, in 2:1-4, which warns of the consequences of disobedience to that salvific, revelatory word (2:1-2), and discloses the folly of attempting to 'flee' to an alternative lordship or neutral territory (2:2-3). The warning forcefully concludes in $2: 4$ with a reminder of the 'signs and wonders and various miracles, and gifts of the Holy Spirit' that the community has been experiencing, both past and present, by which God himself is 'providing corroborating

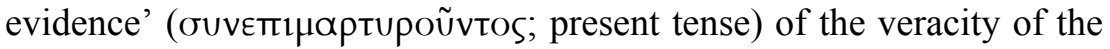
salvific message. ${ }^{6}$ As Paul Ellingworth notes, both prefixes in the rare

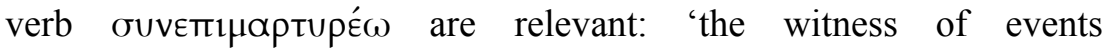

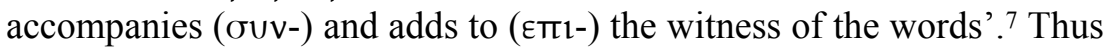

(1992): 21-59, here 41, contends, 'evidence from the warning passages permits us to say that spiritual lethargy had, for some, grown into outright apostasy'. I. Salevao, Legitimation in the Letter to the Hebrews: The Construction and Maintenance of a Symbolic Universe (JSNTSup 219; London/New York: Sheffield Academic, 2002): 249-55, draws attention to the potentially disastrous impact of even a few defections from a small community.

5 In his analysis of Hebrews' emotional 'map', P. S. Perry ('Making Fear Personal: Hebrews 5.11-6.12 and the Argument from Shame', JSNT 32.1 [2009]: 99-125, here 120) observes, 'Confidence is the overwhelming emotional argument of the book'; fear is evoked to increase 'the need for confidence'.

6 The present and ongoing witness of the miraculous in 2:4 is often ignored or denied. So E. Grässer, An die Hebräer (Hebr 1-6) (EKKNT 17/1; Zurich: Benziger/Neukirchen-Vluyn: Neukirchener, 1990): 108; D. A. deSilva, Perseverance in Gratitude: A Socio-Rhetorical Commentary on the Epistle 'to the Hebrews' (Grand Rapids: Eerdmans, 2000): 107; L. T. Johnson, Hebrews (NTL; Louisville/London: Westminster John Knox, 2006): 89. C. R. Koester, Hebrews (AB 36; New York: Doubleday, 2001): 211, claims it is 'not clear whether the author assumed that miracles were still being done in his time or whether the time of miracles had ceased'. H.-F. Weiss, Der Brief an die Hebräer: Übersetzt und Erklärt (KEK 13; Göttingen: Vandenhoeck \& Ruprecht, 1991): 189, expresses similar doubts.

7 Ellingworth, Hebrews, 141. 
the miracles not only verify the gospel message, but they also provide further definition to its content and nature.

Though the precise nature of these "signs and wonders and various

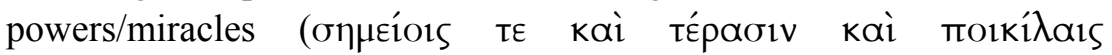
$\delta u v a ́ \mu \varepsilon \sigma ı v)$, and gifts of the Holy Spirit' is left undisclosed, they would surely bring to mind both Jesus and early Church traditions (see esp. Acts 2:22; Rom. 15:19; 2 Cor. 12:12). ${ }^{8}$ The use of these same terms with respect to the community's own experience would then likely indicate that comparable miracles have been occurring in their midst, in conjunction with the proclaimed word. ${ }^{9}$ The entire warning would fall flat if this were not the case. As Luke Timothy Johnson contends: 'This passage is key to the argument of Hebrews as a whole. If these 'confirmations' have not occurred among them, then Hebrews' entire argument is empty and abstract.' ${ }^{10}$ A connection may also be made with 6:5, where the author reminds the recipients of their

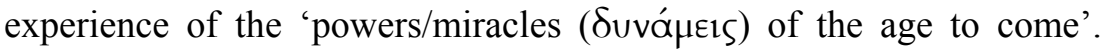
However, in 6:5 he also fails to elaborate on the nature of the powers/miracles, apart from the fact that they originate in the eschaton, and are presently experienced by the community because they live in the liminal 'now, but not yet' eschatological realm inaugurated by the Christ event. As to the 'gifts of the Holy Spirit', the Spirit will play a central role in the two major warning passages $(6: 4 ; 10: 29)$, and perhaps even more significantly, in 10:15 the Spirit will perform a

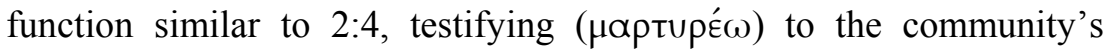

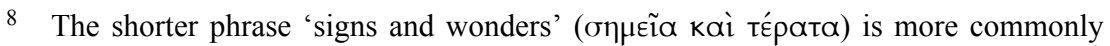

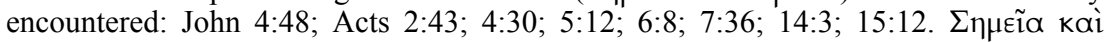
Suvóuєıৎ appears in Acts 8:13.

9 We may assume the eschatological experiences in Hebrews' warnings and exhortations are described in a reliable manner, reflecting the community's experiences with a fair degree of accuracy. Though no one can claim to know or understand the inner life of another individual, the communal nature of the early Church would have presumably engendered an environment in which these experiences were openly discussed and, in some instances, mutually confirmed. The NT accounts of these experiences could, as communal documents, then also be assumed to reflect this process of communal discussion, discrimination, and dissemination. On this, see L. T. Johnson, Religious Experience in Earliest Christianity: A Missing Dimension in New Testament Studies (Minneapolis: Fortress, 1998); L. W. Hurtado, 'Religious Experience and Religious Innovation in the New Testament', Journal of Religion 80 (2000): 183-205. See also G. Griffith-Dickson, Human and Divine: An Introduction to the Philosophy of Religious Experience (London: Duckworth, 2000): 81-144.

10 Johnson, Hebrews, 89. 
forgiveness of sins, sanctification, and cleansed consciences (10:1023).

\subsection{Hebrews 6:4-5}

The next major warning passage, 5:11-6:12, has attracted the most attention, due to its apparent assertion of the 'impossibility' of repentance after apostasy. Occupying a central place in the warning, both rhetorically and structurally, is a string of eschatological experiences the recipients are said to have enjoyed: they have 'been enlightened, tasted the heavenly gift, shared in the Holy Spirit, and tasted the goodness of the word of God and the powers of the age to come' (6:4-5). Of particular interest is the sense of tactility with which these experiences are represented. Though the 'tasting' is of course metaphorical, it is nevertheless intended to characterise the community's thorough immersion in the experience of the eschaton. ${ }^{11}$ They are fully familiar with the flavour of the coming age. And as with the previous warning, 2:1-4, we can assume the descriptions of these supernatural experiences closely corresponded with the recipients' own past and present experiences, or else the warning would be emptied of its force. ${ }^{12}$

The list of supernatural experiences in 6:4-5 is arranged in a string

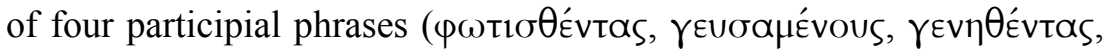

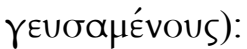

(1) 'Enlightenment' commonly denotes the initial effects of conversion, representing the bestowal of a heavenly perspective, and/or a heightened understanding of divine purposes (John 1:9; Acts 9:3; 22:6-11; 26:13, 18, 23; 2 Cor. 4:4, 6; Eph. 1:18; 3:9; 2 Tim. 1:10; cf. Ps. 33:6; 4 Kgdms. 17:28; 1QH 12; Philo, Fug. 139; T. Levi 4:3; T. Benj. 6:4). ${ }^{13}$ Enlightenment can be constitutive of identity, as those divinely illumined are characterised as 'children of light' (Eph. 5:8-14;

\footnotetext{
11 That Jesus is described as 'tasting ( $\gamma \varepsilon u ́ \omega)$ death for all' in 2:9 would certainly

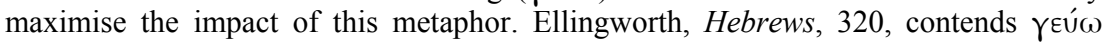
"means "eat" (or "drink"), not merely "taste", hence figuratively "experience (to the full)". See the LXX of Psalm 33:6, 9, where 'enlightenment' ( $\varphi \omega \tau i \zeta \omega)$ and 'tasting' $(\gamma \in \cup ́ \omega)$ spiritual realities are closely coordinated.

12 As Johnson, Hebrews, 162, notes: 'It is not merely a matter of "instruction" that apostates reject, but actual experience'.

13 To Bultmann's credit, 'enlightenment' does come to be closely equated with baptism in such Fathers as Justin (1 Apol. 61.12; 65.1; Dial. 122.5) and Clement of Alexandria (Paed. 1.6.26.2).
} 
1QS). It is frequently contrasted with darkness, and an 'enlightened' person might consider their prior state comparable to blindness (John $8: 12 ; 12: 46 ; 2$ Cor. $4: 4,6$; 1 Pet. 2:9; 1 John $1: 5,7 ; 2: 8-10)$. In the exordium of Hebrews, Jesus is said to 'radiate/reflect' ('̊́maú $\gamma \alpha \sigma \mu \alpha)$ the 'glory' of God (1:3a), and in 2:10 he is depicted as a 'pioneer' leading God's children into that same radiant glory. That the community's 'enlightenment' is mentioned again in the next major warning passage is probably indicative of its importance to them (10:32).

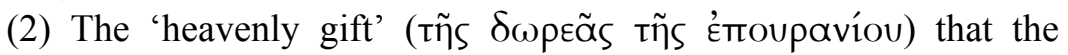
community has 'tasted' is not defined. It probably represents a general reference to salvation and its accompanying benefits (forgiveness, sanctification, the Holy Spirit, access to the heavenly sanctuary). A similarly broad construal of a divine gifting is made in John 4:10 and Romans 5:15-17, while in Acts every occurrence of $\delta \omega \rho \varepsilon \alpha ́$ is directly identified as God's gift of the Holy Spirit $(2: 38 ; 8: 20 ; 10: 45 ; 11: 17)$. In Hebrews, the 'gift' imagery is possibly intended to remind the recipients of the expectations attending the patron-client relationship; i.e. their obligation to respond appropriately to their divine patron's beneficence. ${ }^{14}$

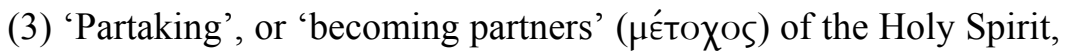
would recall an earlier promise that the recipients 'have become' 'partakers/partners' of Christ, if they persevere in their commitment (3:14). Participatory soteriology probably underlies this imagery. As mentioned before, the Holy Spirit appears in all three of the major warning passages $(2: 4 ; 6: 4 ; 10: 29)$, a fact made all the more remarkable given the paucity of references elsewhere $(3: 7 ; 9: 8,14 ; 10: 15)$. However, Hebrew's portrayal of Jesus, as both immanent and available (2:16-18; 4:14-16; 7:25; 10:19-23; 12:22-24; 13:12-13), would more than adequately make up for any perceived lack of soteriological pneumatology. ${ }^{15}$ Repeated reminders of the community's access to the

14 See deSilva, Perseverance in Gratitude, 223-24.

15 F. J. Matera, 'Moral Exhortation: The Relation between Moral Exhortation and Doctrinal Exposition in the Letter to the Hebrews', Toronto Journal of Theology 10 (1994): 169-82, fails to take this into account in his unfavourable comparison of Hebrews with Paul. In contrast to Paul, he contends, 'Hebrews' view of the moral life is not informed by a doctrine of the Spirit' (178). He also believes Hebrews' portrayal of Jesus, as available and favourably disposed, is 'only a shadow of Paul's doctrine of the Spirit by which the Christian is empowered to do God's will' (182). 
heavenly sanctuary would serve a similar purpose $(4: 14-16 ; 6: 18-20$; $7: 25 ; 10: 19-23 ; 12: 22-24)$.

(4) The community is said to have 'tasted the good word of God and the powers of the coming age' (6:5). Since Hebrews offers what is quite possibly the richest, most multi-faceted understanding of divine address in the New Testament, this reference should extend well beyond the hearing/reading of the LXX, and probably include a number of conceptions found in his own 'word of exhortation': the revelatory nature of the Christ event (1:1-4); the catena of LXX quotations in 1:5-13 vividly describing Jesus' exaltation, presented as direct divine address; the kerygma that brought salvation to the community (2:3); Psalm 95's account of the wilderness wanderings recast as the Holy Spirit's direct address to the community $(3: 7-11,15$; $4: 3,7)$; the representation of the 'word of God' as an all-seeing, allknowing divine instrument of psychological discernment (4:12-13); the rebuke of the community's apparent neglect of the sacred 'oracles' and the 'word of righteousness' (5:11-14; see also 13:7); God's oaths to Abraham (6:13-17) and Jesus (7:20-22, 28); the Torah's role in prefiguring the Christ event (10:1); and the world-creating and destroying 'word of God' (11:3; 12:25-29). Perhaps most pertinent to our discussion are the quotations of the LXX that are presented as the direct addresses of God, Jesus, and the Holy Spirit (1:5-13; 2:12-13; $3: 7-11,15 ; 4: 3,7 ; 5: 5-6 ; 8: 8-12 ; 10: 5-7 ; 10: 15-17,30,37-38 ; 12: 5$; 13:5). As we will see in the next section, at the heart of the author's hortatory program are the dramatised confessions of familial mutuality exchanged by the Father and the Son $(1: 5 ; 2: 12-13)$, and the Son's conferral of family membership on the community (2:12-13).

As we have already noted, the last half of $6: 5$, the 'powers of the age to come', represent the miraculous acts of God that occur in the midst of a community that is straddling the divide separating the present age from the heavenly age to come. The author was convinced the Christ event had inaugurated the eschaton, and Jesus' imminent return from heaven would bring the cataclysmic end of the present evil age, ushering in the heavenly, Messianic era (cf. 1 Thess. 4:13-18; Rom. $13: 11-12$; 1 Pet. 1:3-9). He twice situates his discourse in the 'last days' (Heb. 1:2; 9:26), and in 10:37 makes what is perhaps the most explicit assertion of the eschaton's imminent arrival in the New Testament: the 'Coming One who is coming' will arrive 'in a very little while'. That the lengthy list of eschatological experiences in 6:4-5 
concludes with this somewhat vague phrase may indicate that it represents a précis of the preceding experiences. And though it is not explicitly indicated in this context, the source of these gifts is undoubtedly Jesus, 'the high priest of the good things to come' $(9: 11)$, who rules the 'coming world' (1:5-2:9) from whence these gifts originate.

Finally, Iutisone Salevao has argued at length that the eschatological experiences in 6:4-5 all refer to the 'conversion/initiation event'. ${ }^{16}$ His claim is largely based on the participles' aorist tense, which indicates they 'refer back to a specific moment in the believers' experience, namely, baptism'. ${ }^{17}$ However, Salevao fails to note that the next

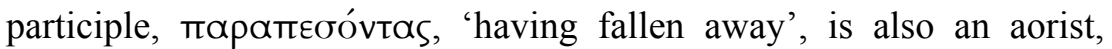
which would suggest that 6:4-6 is entirely situated in the theoretical past. Consequently, the rhetorical focus of the passage is upon the complete (and probably hypothetical) case of persons who have experienced the gifts of the eschaton and then 'fallen away'. And although the adverb "ूँ $\pi \xi \xi$, 'once', might be understood as characterising the enlightenment of 6:4 as a singular, past occurrence, it is best viewed as reflecting an abiding condition. ${ }^{18}$ As 2:4 indicates, God is still presently testifying to the veracity of the gospel message with 'signs and wonders and various miracles'; the eschatological experiences of 6:4-5 should not be relegated to the past either. ${ }^{19}$ Furthermore, the potency of the warning would undoubtedly be enhanced if the community was currently experiencing these eschatological manifestations in their midst, a possibility that has been largely overlooked by almost all critical analyses of this crucial passage.

\footnotetext{
16 Salevao, Legitimation, 285. See also pp. 273-74, 288-89.

17 Salevao, Legitimation, 274.

18 So Koester, Hebrews, 313.

19 Among those who view the eschatological experiences of 6:4-5 as past occurrences: H. W. Attridge, A Commentary on the Epistle to the Hebrews (Hermeneia; Philadelphia: Fortress, 1989): 170; Grässer, Hebräer (Hebr 1-6), 347-48; Weiss, Hebräer, 342; B. Lindars, The Theology of the Letter to the Hebrews (NTT; Cambridge: Cambridge University Press, 1991): 67-68; Johnson, Hebrews, 162; K. L. Schenck, Cosmology and Eschatology in Hebrews: The Settings of the Sacrifice (SNTSMS 143; Cambridge: Cambridge University Press, 2007): 134, 138; J. W. Thompson, Hebrews (Paideia; Grand Rapids: Baker, 2008): 133-34; P. T. O’Brien, The Letter to the Hebrews (Pillar New Testament Commentary; Grand Rapids: Eerdmans, 2010): 220-23.
} 


\subsection{Hebrews 10:26-31}

Perhaps owing to the fact that it follows immediately after the most important exhortation to enter the heavenly sanctuary (10:19-25), the final major warning passage, 10:26-31, mentions only two eschatological experiences. (1) The 'full knowledge of the truth' in 10:26 may be equated with the 'enlightenment' of 6:4. (2) 'Profaning the blood of the covenant by which one was sanctified' (10:29) represents a disavowal of one of the most crucial eschatological

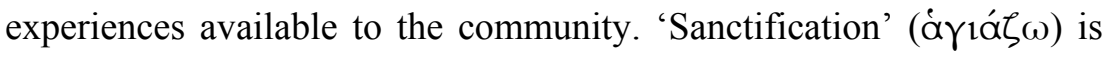
the most commonly encountered cultic soteriological concept in Hebrews $(2: 11 ; 10: 10,14,29 ; 13: 12)$, and it probably represents the second step in a process that began with a cleansing from sin and a defiled conscience $(9: 14 ; 10: 22)$. After having being cleansed, the community has acquired an attribute, 'holiness', which renders them capable of confidently relating to a holy God $(12: 10,14)$. The notion of 'consecration', being dedicated to God and belonging to him, is also inherent in sanctification, as the process of 'being made holy' uniquely joins the community to both the Father and the Son: 'For the one who sanctifies and those being sanctified all have one Father' (2:11; cf. $10: 10 ; 13: 12$ ). This latter sense is also evident in 10:29 with the mention of the covenant. Moreover, since the sanctifying effect of Jesus' atoning death is essential to accessing the heavenly sanctuary $(10: 10,14,19)$, the place where the community's identity is formed, to 'profane the blood ... by which one was sanctified' ultimately represents a disastrous disavowal of one's core identity.

\subsection{Conclusion: Warnings against Apostasy}

The foregoing analysis has demonstrated the importance of the community's eschatological experiences in the three main warning passages. Most surprisingly, Christological assertions are rarely encountered in the warnings: Jesus' 'inescapable' universal lordship is implied in 2:1-4 and the 'Son of God' is mentioned in 6:6 and 10:29. Though the warnings, like other hortatory passages, are organically and structurally connected to surrounding doctrinal assertions, the dire threats issued in the warnings are substantiated almost entirely by the community's past and present eschatological experiences. It also appears that the severity of the warnings is predicated, in part, on the 
author's sense of the magnitude of these eschatological blessings. In this regard, Johnson notes:

The effect of the apostasy is so devastating because of the extraordinary character of the gift received and the cost to Christ of its giving. The enormity of apostasy is measured by the greatness of the experience of God it abandons. That is why it is impossible to 'renew to repentance' people who have proven capable of turning away from their own most powerful and transforming experience. ${ }^{20}$

Although the warnings are substantiated by the supernatural experiences, these experiences would have also inferentially confirmed the eschatological and Christological beliefs that were undoubtedly the primary source of the author's extreme, 'rigorist' attitude towards apostasy. Jesus' absolute lordship (1:2-2:10) disallows the possibility of safely transferring one's allegiance to a rival power (2:1-4), and the imminent end of the present age $(1: 2 ; 9: 26 ; 10: 25,37)$ conveys a heightened sense of irremediable effect of disloyalty. Though a direct connection between eschatological belief and apostasy is not made, it is strongly inferred in the final major warning passage, 10:26-31, which is bound before and aft by a reminder of the visible approach of 'the Day' (10:25), and a promise that Jesus the 'Coming One will come' in 'a very little while' $(10: 37){ }^{21}$

Finally, as we will see in our analysis of the exhortations to persevere, the preeminent eschatological experience in those exhortations pertains to the community's identity as the family of God. Since the role of Jesus the Son (3:1-6) and the confession of his sonship $(1: 5 ; 2: 12-13 ; 4: 14-16 ; 10: 19-23)$ are central to that familial identity, it should not escape our notice that two of Hebrews' three uses of the title 'Son of God' appear in the two direst warnings $(6: 6 ; 10: 29)$. In both instances, bleak characterisations of apostasy climax with vivid portrayals of acts of betrayal committed towards Jesus the Son: apostates 'trample upon' (10:29) and 'treat him with contempt' (6:6); in fact, they are even implicated in his crucifixion (6:6). We may therefore speculate that these references to the 'Son of God' serve as reminders of the community's confession and family identity, and

20 Johnson, Hebrews, 161, 163.

21 Contra Koester (Hebrews, 319) and Salevao (Legitimation, 283-84), who both contend the author's convictions concerning the eschaton's imminence did not influence his views on apostasy. 
highlight the author's conviction that abandoning the community constitutes an irreparable renunciation of that confession and identity.

\section{Exhortations to Persevere}

Functioning as a positive foil to the warnings are Hebrews' numerous and varied exhortations to persevere. In these contexts the community is encouraged to 'hold firmly' to their relationship with Jesus (3:14), their confession of his sonship $(4: 14 ; 10: 23)$, and to 'run with endurance' the contest of faith (12:1-3). An exhortation to 'not neglect our gatherings, as is the habit of some' (10:25) probably constitutes 'the most concrete datum about the problem that Hebrews confronts', ${ }^{22}$ and it maintains the author's emphasis on the corporate nature of Christian existence. Not all these exhortations mention eschatological experiences, which is not surprising, given their prevalence and varied rhetorical contexts. Nevertheless, as we will see, experiential elements play an integral role in some of the most important exhortations to persevere.

\subsection{Hebrews 3:6, 14}

Two of the most significant exhortations to persevere appear in close proximity, $3: 6$ and 3:14, and are quite similar in structure and rhetoric. In 3:6 the community is deemed the 'household (oíkos) of God', if they 'hold firmly (кaté $\chi \omega)$ to the confidence and boast of the hope'; while in 3:14 they 'have become partners with' or 'partakers'

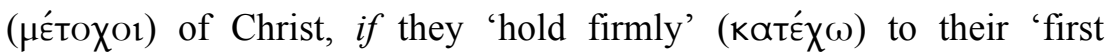
confidence firm to the end'. Perhaps shaped by 'now, not yet' eschatological tension, both verses assume the present possession of an eschatological blessing, the continued enjoyment of which is contingent upon perseverance. In 3:6, the family imagery of $1: 5$ and 2:10-18 is resumed, with this acknowledgement and conditional promise of membership in the household of God. ${ }^{23}$ That the author

\footnotetext{
22 Attridge, Hebrews, 12.

23 Language of belonging and identification is prominent in 2:9-18, reinforcing the Son's conferral of family relatedness in 2:12-13. Familial terminology includes: 'many sons and daughters' (2:10); 'brothers and sisters' (thrice: 2:11-12, 17); 'children' (twice: 2:13-14); 'people' (2:17). The language and imagery of identification is even more pervasive: 'for all' (2:9); 'the founder of our salvation' (2:10); 'the one sanctifying and those being sanctified are all from one source' (2:11); 'congregation' (2:12); 'sharing'/'partaking' (2:14); 'takes an interest' (2:16); 'to become like' (2:17);
} 
primarily conceives of the community as the family of God is apparent in his frequent usage of the term oíkos ('household'), a frequency unsurpassed by any other New Testament writing (ten times: $3: 2-6$; $8: 8,10 ; 10: 21 ; 11: 7) .{ }^{24}$ By contrast, the less personal Ékк $\lambda \eta \sigma i ́ \alpha$ ('congregation') occurs only twice $(2: 12 ; 12: 23)$. Though family language and imagery in the New Testament has typically been characterised as representing a metaphorical, 'fictive kinship', ${ }^{25}$ I believe the author's ultimate objective is to evoke a supernatural encounter of the community with the Father and the Son, which has as its goal the community's adoption into the family of God. The desired outcome of this encounter would be the creation of an enduring family identity that was in no way inferior to that experienced within biological families. ${ }^{26}$

The conditional statement of 3:14, that the community 'has become' ( $\gamma \varepsilon \gamma o ́ v \alpha \mu \varepsilon v$; perfect tense) 'partakers of', or 'partners with' Christ (не́тохо тои̃ Хрıбтои̃), if they persevere in their commitment, is also quite significant. ${ }^{27}$ The concepts of partaking and sharing recur in

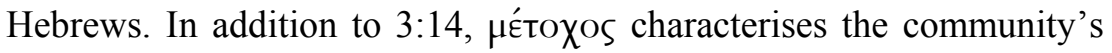
'participation' in a 'heavenly calling' (3:1), the Holy Spirit (6:4), and the 'discipline' of God (12:8). Furthermore, they 'share flesh and

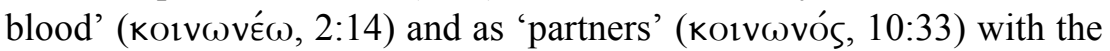
persecuted church they should share in their sufferings. They will also 'share' ( $\mu \varepsilon \tau \alpha \lambda \alpha \mu \beta \alpha$ v $\omega)$ in their heavenly Father's holiness, should they submit to his 'discipline' (12:10). More important, though, are the author's assertions that the Son has 'partaken' of the human condition

'because he was tested in sufferings he is able to help those who are being tested' (2:18). In 2:10 God, the source and teleological goal of humanity, appropriately desires that 'many siblings be led to glory'.

24 J. Dunnill, Covenant and Sacrifice in the Letter to the Hebrews (SNTSMS 75; Cambridge: Cambridge University Press, 1992): 34, contends, 'oíkos is certainly the author's primary group concept'.

25 See R. Aasgaard, 'My Beloved Brothers and Sisters!' Christian Siblingship in Paul (JSNTSup 265; London: T\&T Clark, 2004).

26 High mortality rates in the ancient Mediterranean world would have probably made family relationships rare and dear. B. Rawson, "The Roman Family" in Recent Research: State of the Question', BibInt 11 (2003): 119-38, here 129, observes: 'Few of our sources evoke a picture of a household full of brothers and sisters in the way that some more modern sources do. If in Roman families close sibling relationships were more rare, that might, of course, have made them more precious'. See also S. R. Hübner and D. M. Ratzan, eds, Growing Up Fatherless in Antiquity (Cambridge: Cambridge University Press, 2009).

27 Métoxos may be taken as an adjective, 'sharing' or 'participating in', or a noun '(business) partner' or 'companion' (BDAG, 643). 
( $\mu \in T E ́ \chi \omega, 2: 14)$, being 'made in every respect like his siblings' (2:17). Given the close proximity of 3:14 to chapter two's profuse

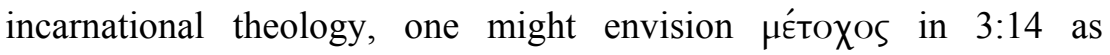
reflecting the logical corollary of a pattern of mutuality and reciprocity. The Son has fully joined himself to his people so that they might become completely united with him; thus they are 'participants in Christ's reality', 'partaking of his very existence'. Despite some

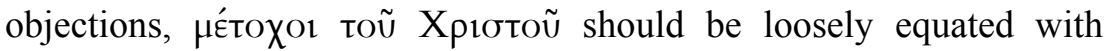
Paul's 'in Christ' participatory soteriology: the community is standing in the sphere of Christ's existence and influence. ${ }^{28}$

\subsection{Hebrews 4:1, 3, 11}

The next significant exhortation to persevere appears in 4:1-11, where the author commends the diligent pursuit of entry into the divine 'rest' (кatómavoıৎ). Like 3:6 and 3:14, these exhortations are also shaped by an eschatological, 'now, not yet' tension. Although those 'who

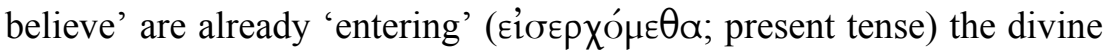
rest (4:3), Hebrews nevertheless encourages the community to 'make every effort to enter that rest, so that no one may fall through disobedience' (4:11). Therefore, the rest is 'both present and future: men enter it, and must strive to enter it'. ${ }^{29}$ Failure to recognise the tension has led many to see it as an either/or issue, with some viewing the rest as unfulfilled and future, ${ }^{30}$ while others consider it present and realised. ${ }^{31}$ George H. Guthrie has also made a convincing case for equating the rest with present and future entry into the heavenly

28 Contra Ellingworth, Hebrews, 227.

29 C. K. Barrett, 'The Eschatology of the Epistle to the Hebrews' in The Background of the New Testament and Its Eschatology: Essays in Honour of C. H. Dodd, ed. W. D. Davies and D. Daube (Cambridge: Cambridge University Press, 1956): 363-93, here 372. A. T. Lincoln, 'Sabbath, Rest, and Eschatology in the New Testament' in From Sabbath to Lord's Day: A Biblical, Historical, and Theological Investigation, ed. D. A. Carson (Grand Rapids: Zondervan, 1982): 197-220, esp. 212, also acknowledges this eschatological tension.

30 J. Laansma, 'I will give you rest': The Rest Motif in the New Testament with Special Reference to Matthew 11 and Hebrews 3-4 (WUNT 2/98; Tübingen: Mohr Siebeck, 1997): 334; Koester, Hebrews, 270; Weiss, Hebräer, 279.

31 A. T. Lincoln, Hebrews: A Guide (London: T\&T Clark, 2006): 73, 80; A. Vanhoye, 'Sanctuaire terrestre, sanctuaire céleste dans l'épître aux Hébreux' in Quelle Maison pour Dieu?, ed. C. Focant (LD; Paris: Cerf, 2003): 351-94, esp. 361; D. A. deSilva, 'Entering God's Rest: Eschatology and the Socio-Rhetorical Strategy of Hebrews', Trinity Journal 21 (2000): 25-43, esp. 32; J. H. Wray, Rest as a Theological Metaphor in the Epistle to the Hebrews and the Gospel of Truth: Early Christian Homiletics of Rest (SBLDS 166; Atlanta: Scholars Press, 1998): 86. 
sanctuary, based on extensive verbal parallels linking 3:7-4:13 with 4:14-16 and 10:19-25. 32

\subsection{Hebrews 4:14-16 and 10:19-23}

In 4:14-16 and 10:19-23 the author combines his two principal hortatory imageries: (1) static imagery of 'holding firmly' (крат́́ $\omega$, $4: 14$; KaTÉ $\chi \omega, 10: 23)$ to the community confession, denoting patient and determined perseverance (cf. 3:6, 14); (2) dynamic movement imagery enjoins the community to 'draw near' the 'throne of grace' (4:16) and 'confidently enter the holy place' (10:19-23; cf. 4:1, 3, 11; $6: 18-20 ; 12: 22-24) .{ }^{33}$ Both imageries are essential: perseverance entails determined, steadfast faithfulness as well as forward progress and growth.

These two contexts, 4:14-16 and 10:19-23, are perhaps the two most important passages in the entire 'word of exhortation'. In my previous analyses of these exhortations, I contend that the content of the community's confession is Jesus' sonship, it is reciprocative in nature, and it occurs within the framework of a dramatic enactment of the Son's exaltation. ${ }^{34}$ The first act in the author's dramatisation of Jesus' exaltation (chs. 1 and 2) prominently features mutual confessions of familial relatedness exchanged between the Father (1:5) and the Son

32 G. H. Guthrie, 'Strive to Enter - What?: Hebrews' Appropriation of the "Entering Rest" Motif' (unpublished paper, SBL Annual Meeting, Atlanta, GA., 24 November 2003). C. M. Pate, Communities of the Last Days: The Dead Sea Scrolls, the New Testament \& the Story of Israel (Downers Grove: IVP, 2000): 205, also links the 'coming eschatological rest' with 'the true, heavenly temple or some similar metaphor'. Lincoln, 'Sabbath, Rest, and Eschatology', 207, notes that the author never defines the rest, rather he 'seems to presuppose that its significance will have been readily understandable to his readers'. It has been understood variously as representing either a place (i.e. the heavenly sanctuary) or a state (God's own state of rest). C. R. Koester, 'God's Purposes and Christ's Saving Work According to Hebrews' in Salvation in the New Testament: Perspectives on Soteriology, ed. J. G. van der Watt (NovTSup 121; Leiden: Brill, 2005): 361-87, here 376, aptly remarks: 'To enter rest is not merely to enter a place, but to enter God's own rest, a rest that is inseparable from God himself'.

33 So Attridge, Hebrews, 21-22. Furthermore, the verbs of motion that characterise the disobedience of Israel in the wilderness (3:7-4:11) meet their rhetorical foil in the repeated exhortations to enter the heavenly sanctuary. Obedience is thus enacted through the verbs of forward motion and entry that have as their goal the heavenly sanctuary and God's presence.

34 See Eschatology and Exhortation, 216-30; 'Confession of the Son of God in Hebrews', NTS 53 (2007): 114-29; 'Confession of the Son of God in the Exordium of Hebrews', JSNT 30 (2008): 437-53; 'Heavenly Sanctuary Mysticism in the Epistle to the Hebrews', JTS 62 (2011): 77-117. 
(2:12-13); it also depicts the Son conferring family membership on the community (2:12-13). The presence of the community in this drama is implied by the manner in which the Father and Son's declarations are presented. After the Father directly addresses the exalted Son in 1:5: 'You are my Son; today I have begotten you', he speaks of the Son in the third person: 'I will be his Father, and he will be my Son'. The Son's response, dramatically enacted in 2:12-13, follows the same pattern: 'I will proclaim your name to my brothers and sisters, in the midst of the congregation I will praise you ... I will put my trust in him ... Here am I and the children whom God has given me.' In both passages the speeches of the dramatis personae shift from second person to third person address, a shift possibly inferring the community's presence in the heavenly sanctuary, as participants in the drama and the objects of divine address. The presence of the recipients may be explicitly indicated in 2:13: 'Behold! (íoú) I am with the children whom God has given me.' The ultimate goal of the author's hortatory effort would then be achieved in 4:14-16 and 10:19-23, as the community enters the heavenly sanctuary and confesses Jesus' divine sonship. ${ }^{35}$ This confession is reciprocative in nature, responding to Jesus' conferral of family membership in 2:12-13, thereby actualising their adoption into the family of God. It is therefore truly an act of 'saying the same things' (óo- $\lambda$ oría) that God (1:5) and the Son (2:12-13) have said to each other and the community. That this confession is to be 'firmly held' indicates a single confession is not all that is intended here; rather, what is envisaged is an ongoing orientation towards sonship confession, to be 'boldly offered' in both the sacred and public spheres.

35 In 'Heavenly Sanctuary Mysticism', 87-99, and 'Ancient Jewish Mystical Motifs in Hebrews' Theology of Access and Entry Exhortations', NTS 58.1 (2012): 88-104, I discuss at length the nature of the exhortations to 'draw near'. I contend they represent a substantial mystical experience, reflecting the author's expectation of either a communal heavenly ascent or an opening of the community's eyes of faith to a theophanic manifestation of God and his Son in the congregation. Despite this uncertainty, the heightened emotional tenor, crucial hortatory importance, and extraordinary theological content of the two primary entry passages, 4:14-16 and 10:19-23, allows us to be reasonably certain of their mystical function, as intending to evoke a liminal border crossing, from the earthly gathering into the very presence of God and his Son in the heavenly sanctuary. Moreover, with his declaration that the

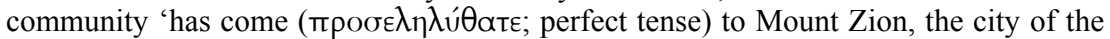
living God, the heavenly Jerusalem' (12:22), the author appears to signal his confidence in the success of the earlier entry exhortations. 


\subsection{Hebrews 12:1-3}

Vivid athletic imagery is employed in 12:1-3 to encourage the community to persevere in their commitment. In the contest of faith they must 'not grow weary or lose heart', rather they should 'run with endurance the race that is set before them' ${ }^{36}$ Also, on two occasions the author commends visual apprehension of Jesus: in 12:2, the community is told to 'look ('́)popá $\omega$ ) to Jesus the pioneer and perfecter of our faith', and in 12:3, they are to visually recollect

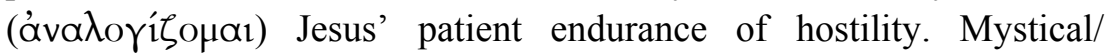
eschatological visuality is essential to Hebrews' hortatory effort. Given the community's experience of suffering, which was causing them to contemplate abandoning their commitment, one of the author's main goals is to get them to 'see' into the heavenly future, past their earthly present, nearly engulfing experience of suffering. ${ }^{37}$ This he attempts by means of the rhetorical practices of ekphrasis and enargeia, which would help evoke an eschatological vision of Jesus' victory over suffering, conquest of death, and glorious exaltation. ${ }^{38}$ Though in their earthly circumstances they are unable to perceive the effects of Jesus' exaltation to lordship $(2: 8)$, the author exhorts the community to look into the heavenly realm (vividly portrayed in $1: 5-13 ; 2: 12-13 ; 8: 1-2$; 9:11-12; 12:22-24), where they will see Jesus, "who for the joy set before him endured the cross, despising the shame, and has sat down at the right hand of the throne of God' $(12: 2$; cf. 2:9; 4:14-16; 9:24; 10:12, 19-21). Like Moses, the community will find the impetus and strength to 'persevere by seeing him who is invisible' (11:27). ${ }^{39}$

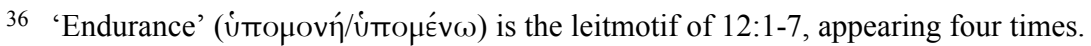

37 The author repeatedly characterises Jesus' death as involving 'suffering' (2:9-10, $18 ; 5: 8 ; 9: 26 ; 13: 12)$. Furthermore, a hortatory pattern of suffering leading to glorification recurs throughout Hebrews $(1: 3 ; 2: 5-18 ; 4: 14-16 ; 5: 7-10 ; 10: 12,32-39$; $12: 1-11 ; 13: 12-14)$.

38 G. Zanker, Modes of Viewing in Hellenistic Poetry and Art (Madison: University of Wisconsin Press, 2004): 6-7, defines ekphrasis as a 'vividly pictorial literary description' that represents 'the ocular presentation in literature of any phenomenon in nature and culture'. The definitive treatment is Ruth Webb, Ekphrasis, Imagination and Persuasion in Ancient Rhetorical Theory and Practice (Farnham, UK/Burlington, VT: Ashgate, 2009).

39 For a discussion of Hebrews' mystical visual program, see my 'Heavenly Sanctuary Mysticism', 99-116.
} 


\subsection{Hebrews 12:5-17}

In Hebrews' lengthiest exhortation to persevere, 12:5-17, the community's experience of family belonging offered in 2:12-13, and achieved in 4:14-16 and 10:19-23, is enlisted in the service of an elaborate and suggestive piece of theodicy. The author's primary goal in this passage is to transform the community's view of their earthly sufferings, which may have been seen by them as an indication of divine disfavour, or a refutation of the early Church's claims of Jesus' exaltation to universal lordship. ${ }^{40}$ By transferring the locus of their experience of social marginalisation and possible persecution to the heavenly plane and attributing it to God, who is portrayed as administering beneficial parental 'discipline' ( $\pi \alpha 1 \delta$ cía, 12:5-10), the community's sufferings, like those endured by Jesus (5:7-10), are represented as normative, necessary, and even advantageous. ${ }^{41}$

Hebrews carefully skirts the issue of exactly how God is involved in the recipients' persecution and sufferings. ${ }^{42}$ It is most likely they are encountering opposition as a result of their membership in the community, and their confession of Jesus as the Son of God. That the community's family identity is the primary source of their sufferings is evident throughout the passage. The author prefaces a quotation of Proverbs 3:11-12, which discusses the necessity of paternal discipline ( $\pi \alpha 1 \delta \varepsilon i \alpha)$, with the claim that this LXX text issues an 'exhortation which addresses you as sons and daughters' (12:5a). His exegesis of this passage maintains its familial language and imagery (viós: three

\footnotetext{
40 A context of persecution is probably implied in 12:4-11: as Jesus' encounters with 'sinners' led to his crucifixion (12:3), so the recipients' struggle against 'sin' could also potentially lead to bloodshed (12:4; cf. 10:32-36). Furthermore, the only other

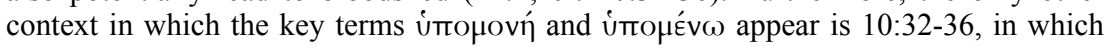
the community's prior 'endurance' of persecution is recalled. N. C. Croy, Endurance in Suffering: Hebrews 12:1-13 in Its Rhetorical, Religious, and Philosophical Context (SNTSMS 98; Cambridge: Cambridge University Press, 1998): 163, notes: 'Although the language of suffering is not found in 12:1-13, the community's experience of it is assumed and interpreted there'.

41 On $\pi \alpha_{1} \delta \varepsilon i \alpha$ and the positive view of corporeal punishment in the ancient Mediterranean world, see R. S. Dutch, The Educated Elite in 1 Corinthians: Education and Community Conflict in Graeco-Roman Context (JSNTSup 271; London: T\&T Clark, 2005): 184-91, 261-78; J. T. Fitzgerald, 'Proverbs 3:11-12, Hebrews 12:5-6, and the Tradition of Corporeal Punishment' in Scriptures and Traditions: Essays on Early Judaism and Christianity in Honor of Carl R. Holladay, ed. P. Gray and G. R. O'Day (NovTSup 129; Leiden: Brill, 2008): 291-317.

42 The author is similarly reluctant to ascribe Jesus' death to God. Though Jesus' death is attributed to divine 'necessity' $(2: 10)$, it is never directly connected to God's agency. Cf. Isaiah 53:4-6, 10.
} 
times in 12:7-8; тати́p: three times in 12:7, 9), and concludes with the cautionary tale of Esau, who traded his family status for a single meal (12:16-17). ${ }^{43}$ The author thus attempts to redefine the community's sufferings, contending they serve to refine and define their allegiance to the family of God. Their sufferings even function as a sort of divine paternity test, determining whether or not they are God's children (12:7-8). By implication, if they take steps to evade or eliminate the 'discipline'/persecution, by leaving the community, they will have revealed their 'illegitimacy', visibly demonstrating they are not the 'sons and daughters of God' (12:8).

Positively, the sufferings are said to be instrumental in imparting some of God's attributes to his sons and daughters, including life (12:9), holiness (12:10), and the 'peaceful fruit of righteousness' (12:11). ${ }^{44}$ And most remarkably, 'partaking' of God's holiness will afford the community a mystical/eschatological vision of God (ópá $\omega$, 12:14). This accords with the well-attested ancient Jewish belief that sensory reliability and clarity is directly related to morality: clean living affords clear seeing (Deut. 29:2-4; 1 John 3:6; 1QS 4:11; 5:5; 1 En. 89-90; T. Dan. 2:3-5; T. Benj. 6; Let. Aris. 142; 155-157; Philo, Ebr. 83; Mut. 82; Spec. 2:44-46; Contempl. 11-12; 68; 78; 87; 89; QE 2:51). However, given the passage's emphasis on family, and the absence of moral issues, it is more probable that holiness represents consecration, i.e. belonging to God, as his children. Consequently, this unequivocal promise of an eschatological vision of God applies to those whose experience of belonging to God has led them to willingly endure the sufferings that necessarily attend membership in God's family and public identification with his Son.

43 M. Thiessen, 'Hebrews 12.5-13, the Wilderness Period, and Israel's Discipline', NTS 55 (2009): 366-79, minimises this pervasive familial language and imagery and argues instead that Israel's wilderness wanderings constitute the primary background imagery for 12:5-13.

44 The NT commonly portrays suffering in a positive light (cf. 1 Pet. 1:6-7; Rom. 5:34; Jas 1:3-4; Rev. 3:19). Seneca also considers suffering evidence of God's paternal love, and essential for the acquisition of endurance, strength, and other virtues $(\mathrm{On}$ Providence 2.6-7; 4.7, 11-12). See also Philo, Congr. 177, who defends the benefits and necessity of suffering, quotes Prov. 3:11-12, and comments: 'We see that reproaching and admonition are counted an excellent thing, as they turn our confession of God into kinship with him. For what relation can be closer than that of a father to sons and daughters, or of sons and daughters to a father?' Furthermore, Congr. 163-80 shares a number of terms and motifs with Hebrews 12:1-17: 'bitterness', weakening limbs, life as an agonistic/athletic contest, turning away, 'profane' people, 'painful', Esau, 'peaceable', 'justice/righteousness', and gymnastic training. 


\subsection{Conclusion: Exhortations to Persevere}

Though eschatological experiences are not as commonly encountered in Hebrews' exhortations to persevere, they appear in some of the most important exhortations, and are therefore instrumental to the overall success of his hortatory effort. The experiences in the exhortations are often characterised by a 'now, not yet' eschatological tension, which works in concert with conditional promises offered by the author. Thus the community is said to be presently enjoying key eschatological blessings, such as divine rest, an intimate connection with Jesus, and membership in the family of God, though their continued, and ultimate enjoyment of these blessings is dependent upon faithful perseverance 'until the end' $(3: 6,14 ; 4: 1,3,11 ; 12: 5-17)$. The primary experiential motif found in these exhortations pertains to the community's relatedness to Jesus, and their identity as the family of God $(3: 6,14$; $4: 14-16 ; 10: 19-23 ; 12: 5-17)$. The author places great rhetorical weight on the power of the community's sense of belonging in God's family. Presumably he expects this unparalleled experience would instill a commensurate awareness of the expectations and obligations that attend membership in that family.

\section{The Mutual Interdependence of Christology, Exhortation, and Eschatological Experience}

Though many have noted Hebrews' seamless interweaving of doctrine and exhortation, this essay has attempted to demonstrate that the community's eschatological experiences are just as tightly woven into the fabric of his 'word of exhortation'. Hebrews' 'hortartory logic' is therefore comprised of three essential elements, as both his high priest and Son of God Christologies are inseparably joined to distinct hortatory efforts and appeals to unique experiences. For example, in 10:19-23 the author's confidence in the accuracy and efficacy of his high priest Christology and its corresponding cultic soteriology is evidenced by his exhortation to 'draw near' and 'enter the heavenly sanctuary' through the cultic achievement of Jesus, which has come to expression in the community's experience of their 'hearts' being 'sprinkled clean from an evil conscience' and their 'bodies' having been 'washed with pure water' (10:22). The warning against 'profaning the blood of the covenant by which one was sanctified' (10:29) testifies 
to a comparable close linkage of high priest Christology, exhortation, and cultic eschatological experience. Similarly, assertions that the Son of God's obedient endurance of sufferings had issued in his exaltation to the right hand of God $(2: 5-9 ; 5: 7-9)$ would be confirmed by the calls to 'see' Jesus glorified $(2: 9,12-13 ; 3: 1 ; 12: 2-3)$, the entry exhortations, and especially the dramatic enactment of the community's adoption into the family of God (2:12-13). As should now be apparent, both Christologies and their attendant hortatory and experiential appeals converge and coalesce in the community's entry into the heavenly sanctuary.

Further evidence of a tight connection between Christological doctrine, the author's hortatory program, and the community's eschatological experiences, is apparent in the recurring conviction that abandoning the community constituted an irrevocable act of betrayal. The eschatological experiences were not impersonal and inconsequential flashes from the heavens, rather, they were tangible foretastes of the coming, heavenly age, and life-transforming gifts bestowed at great cost by Jesus, 'the high priest of the good things to come' (9:11) and the elder brother of the community (2:12), upon his siblings. The community's encounter with the exalted and enthroned Son in the heavenly sanctuary should have also convinced them of a number of things, including the folly of attempting a flight to a rival lordship or neutral territory, as well as the reliability of the promise that they would soon find their ignominious circumstances overturned. Even more significant in this regard is their experience of adoption, enacted in the presence of God and his Son in the heavenly sanctuary, which should have persuaded them that abandoning the community represented a forfeiture of identity and a betrayal of family.

\section{Conclusion}

To a community whose probable conditions of social marginalisation and suffering were causing them to contemplate a departure from the 'household of God', the Epistle to the Hebrews offers an impassioned, yet carefully reasoned plea for faithful perseverance. Hebrews clearly reflects the fruit of a lifetime spent working through the practical and theological implications of the Christ event, and years of pastoral experience spent applying those implications to early Christian 
communities. It also testifies to the early Christian belief that, in the wake of the Christ event, God was acting through his Son to provide his people with numerous powerful and empowering proofs of his love and commitment. Hebrews is particularly noteworthy for the manner in which it personally involves the community in the story of God's redemptive love, habitually connecting their experiences of the eschaton to a larger narrative of Jesus' sacrificial self-offering and glorious exaltation. The author not only attempts to remind the community of their place in this larger narrative, but he also seeks to elicit an even greater level of participation in and commitment to its unfolding story. With hindsight, we may agree that he was justified in his expectation of a favourable outcome in this regard (6:9), and the preservation of his masterful 'word of exhortation' may well testify to its success in doing just that. 